\title{
ANALISIS KETAATAN KARYAWAN DALAM PEMERIKSAAN KESEHATAN BERKALA DI RUMAH SAKIT PKU MUHAMMADIYAH KOTA YOGYAKARTA
}

\author{
Afridah Salhah, Agus Suwarni, Widodo Hariyono \\ Fakultas Kesehatan Masyarakat, Universitas Ahmad Dahlan, Yogyakarta
}

\begin{abstract}
Background: The hospital is one workplace where there is staff, patients, visitors, medical devices and non-medical, so in the hospital there are a variety of exposures, among others, chemical, biological, ergonomics. Employees at the hospital is a potential resource that must be nurtured to become productive and quality. But apparently in carrying out daily sociality services especially in the work environment, employees are more exposed to the various factors that may cause negative impact and affect their health status. Employees in hospitals vary greatly in terms of type and number in executing its duties is always associated with a variety of potential hazards if not properly and correctly anticipated to have a negative impact on safety and health, which in turn can affect the productivity of work. Low labor productivity will also have an impact on health services provided by the hospital. The implementation of occupational safety and health program (K3) in the hospital is required to prevent various hazards that may cause health effects. However, the implementation of K3 in particular areas of work on employee health in RS PKU Muhammadiyah Yogyakarta has not fully run optimally, citing the cost is relatively expensive.

Method: This study was an observational study that was descriptive qualitative located in RS PKU Muhammadiyah Yogyakarta. The subjects consisted of Chairman PK3, PK3 Secretary, and 50 permanent employees in RS PKU Muhammadiyah Yogyakarta.

Results: Based on the research of 52 employees, obtained results showed that the level of employee compliance in following the health checks can be quite good even as many as $65 \%$.

Conclusion: Factors inhibiting the implementation of occupational health in RS PKU Muhammadiyah Yogyakarta is the lack of socialization from the hospital to its employees, employee behavior, and no sanctions for employees who do not want to follow the program. While the reasons for employees to check their health on a regular basis is self-protection, and to know his health. Compliance level employees in the following periodic medical examinations in hospitals PKU Muhammadiyah Yogyakarta good enough. Level of occupational health services in RSU PKU Muhammadiyah Yogyakarta good enough.
\end{abstract}

Keywords: Analyze, Employees Compliance, the Periodic Health Examination

\section{PENDAHULUAN}

Rumah sakit merupakan salah satu tempat kerja yang di dalamnya terdapat karyawan, pasien, pengunjung, alat-alat medis dan non medis sehingga di dalam rumah sakit terdapat berbagai paparan antara lain: kimia, biologi, ergonomi. Keselamatan dan kesehatan kerja (K3) di rumah sakit Sudah saatnya mendapatkan perhatian khusus. ${ }^{1}$ Selain itu, rumah sakit juga termasuk ke dalam kriteria tempat kerja dengan berbagai ancaman bahaya yang dapat menimbulkan dampak kesehatan, tidak hanya terhadap pada pelaku langsung yang bekerja di rumah sakit, tetapi juga terhadap pasien maupun pengunjung rumah sakit, sehingga sudah seharusnya pihak pengelola rumah sakit menerapkan K3 di rumah sakit. ${ }^{2}$ Keselamatan dan kesehatan kerja merupakan hal yang penting dalam setiap proses operasional industri. Berkembangnya industrialisasi di Indonesia, sejak awal disadari tentang kemungkinan timbulnya dampak terhadap karyawan maupun terhadap masyarakat sekitarnya. ${ }^{3}$

Keselamatan dan kesehatan kerja mempunyai maksud memberikan perlindungan terhadap karyawan sekaligus melindungi aset perusahaan. Hal ini tercantum dalam 
Undang-undang Nomor 1 Tahun 1970 tentang Keselamatan Kerja bahwa setiap tenaga kerja barhak mendapatkan perlindungan atas keselamatan dalam melakukan pekerjaan, dan setiap orang lainnya yang berada di tempat kerja perlu terjamin keselamatannya, serta sumber produksi dipakai dan dipergunakan secara aman dan efisien sehingga proses produksi berjalan dengan lancar. ${ }^{4}$

Karyawan di rumah sakit merupakan sumberdaya potensial yang harus dibina agar menjadi produktif dan berkualitas. Namun, ternyata dalam melaksanakan jasa kemasyarakatannya sehari-hari khususnya dalam lingkungan kerjanya, karyawan banyak terpapar dengan berbagai faktor yang dapat menimbulkan dampak negatif dan mempengaruhi derajat kesehatan mereka. Karyawan di rumah sakit yang sangat bervariasi dari segi jenis maupun bidang tugasnya selalu berhubungan dengan berbagai bahaya potensial bila tidak diantisipasi dengan baik dan benar yang dapat menimbulkan dampak negatif terhadap keselamatan dan kesehatannya, yang pada akhirnya dapat mempengaruhi produktivitas kerjanya. Produktivitas kerja yang rendah akan berdampak pula terhadap pelayanan kesehatan yang diberikan oleh rumah sakit. ${ }^{5}$

Pelaksanaan K3 di rumah sakit ternyata belum sebagaimana mestinya. Penyebabnya komplek, mulai dari ketidaktahuan karyawan, rendahnya perhatian manajemen, sampai kepada lemahnya aspek pengawasan pemerintah. Padahal sasaran K3 adalah untuk menciptakan keamanan, kenyamanan dan kesehatan karyawan, sehingga dapat meningkatkan produktivitas kerja. Tempat kerja sebagai wahana informasi sekaligus tempat interaksi karyawan dengan faktor risiko, maka tanpa pelaksanaan $\mathrm{K} 3$, karyawan terancam kecelakaan kerja termasuk penyakit akibat kerja. ${ }^{6}$

RS PKU Muhammadiyah adalah salah satu rumah sakit swasta di Yogyakarta yang merupakan amal usaha Pimpinan swasta di Yogyakarta yang merupakan amal usaha Pimpinan Pusat Persyarikatan Muhammadiyah. Merupakan rumah sakit terakreditasi 12 bidang pelayanan dengan tipe $C$ plus. Selain memberikan pelayanan kesehatan juga digunakan sebagai tempat pendidikan bagi calon dokter dan pesawat. Visi RS PKU Muhammadiyah Yogyakarta adalah menjadi Rumah Sakit Islam yang berdasar pada AI Qur'an dan Sunnah Rasullullah SAW, dan sebagai rujukan terpercaya di Daerah Istimewa Yogyakarta dan Jawa Tengah dengan kualitas pelayanan kesehatan yang Islami, profesional, cepat, nyaman dan bermutu, setara dengan kualitas pelayanan rumah sakit terkemuka di Indonesia dan Asia. Misi RS PKU Muhammadiyah Yogyakarta ${ }^{7}$ adalah:

1. Mewujudkan derajad kesehatan yang optimal bagi semua lapisan masyarakat melalui pendekatan pemeliharaan, pencegahan, pengobatan, pemulihan kesehatan secara menyeluruh sesuai dengan peraturan atau ketentuan perundang-undangan.

2. Mewujudkan peningkatan mutu bagi tenaga kesehatan melalui sarana pelatihan dan pendidikan yang diselenggarakan secara profesional dan sesuai tuntunan ajaran Islam

3. Mewujudkan da'wah Islam, amar ma'ruf nahi munkar di bidang kesehatan dengan senantiasa menjaga tali sillaturrahim, sebagai bagian dari da'wah Muhammadiyah

Hasil wawancara pada survei pendahuluan menunjukkan bahwa sejak tahun 1999, RS PKU Muhammadiyah Kota Yogyakarta telah melaksanakan program K3 sebagai bentuk implementasi dari Undang-undang Nomor 1 Tahun 1970 tentang Keselamatan Kerja. Dengan tujuan untuk membangun, melengkapi dengan peralatan, menjalankan dan memelihara tempat sumber daya yang tersedia sedemikian rupa untuk menciptakan suasana dan lingkungan kerja yang sehat dan aman. Programprogram yang dilaksanakan meliputi : bidang kesehatan kerja, bidang keselamatan kerja, bidang penyehatan lingkungan rumah sakit, dan bidang kebakaran dan kewaspadaan bencana. Pelaksanaan K3 khususnya bidang kesehatan kerja pada karyawan di RS PKU Muhammadiyah Kota Yogyakarta belum sepenuhnya berjalan secara optimal, dengan alasan biaya yang dikeluarkan relatif mahal. Pada pemeriksaan

KES MAS Vol. 5, No. 1, Januari $2011: 1$ - 67 
kesehatan awal telah dilakukan pada calon karyawan, tetapi pada pemeriksaan kesehatan berkala yang diselenggarakan tiap tahun sekali tidak dilakukan kepada seluruh karyawan dikarenakan keterbatasan biaya sehingga dilakukan secara bergantian dari tiap tahunnya. Hal ini akan menyebabkan kesehatan karyawan dalam kondisi yang tidak terkontrol dan dapat mempengaruhi produktivitas kerjanya.

Berdasarkan permasalahan di atas, maka perlu dilakukan " Analisis Ketaatan Karyawan dalam Pemeriksaan Kesehatan Berkala di RS PKU Muhammadiyah Kota Yogyakarta ". Melalui analisis tersebut, diharapkan menjawab permasalahanpermasalahan yang terkait dengan K3 khususnya pemeriksaan kesehatan berkala di RS PKU Muhammadiyah Kota Yogyakarta, sehingga dapat meningkatkan kinerja dan mutu pelayanan rumah sakit, serta dapat menciptakan suasana kerja yang aman, nyaman, efisien dan produktif.

\section{METODE PENELITIAN}

Penelitian ini termasuk jenis penelitian observasional dengan rancangan yang bersifat deskriptif kualitatif. Penelitian ini bertujuan untuk mengetahui dan memperoleh informasi yang lebih mendalam tentang pemeriksaan kesehatan berkala di RS PKU Muhammadiyah, sehingga dapat memberikan pemahaman yang lebih mendalam. ${ }^{8}$ Subyek penelitian ini adalah Ketua PK3, Sekretaris PK3, dan 50 orang karyawan tetap di RS PKU Muhammadiyah Kota Yogyakarta.

\section{HASIL PENELITIAN DAN PEMBAHASAN}

a. Hasil Penelitian

1) Karakteristik Responden

Tabel 1. Karaktesistik Responden pada Karyawan RS PKU Muhammadiyah Yogyakarta Tahun 2010

\begin{tabular}{lcc}
\hline \multicolumn{1}{c}{ Karakteristik } & Frekuensi (F) & Persentase (\%) \\
\hline 1. Jabatan & & \\
Manajer & 1 & 1,9 \\
Supervisor & 5 & 9,6 \\
Pelaksana & 21 & 40,4 \\
2. Pendidikan & & \\
SD & 1 & 1,9 \\
SLTA & 3 & 5.8 \\
SMA & 12 & 23,0 \\
Diploma/Akper & 30 & 57,7 \\
S1/S2 & 6 & 11,5 \\
\hline \multicolumn{1}{c}{ Jumlah } & $\mathbf{5 2}$ & $\mathbf{1 0 0 , 0}$ \\
\hline
\end{tabular}

Berdasarkan tabel di atas responden penelitian dengan jabatan pelaksana $(40,4 \%)$ lebih banyak dari jabatan supervisor $(9,6 \%)$ dan responden penelitian terbanyak lulusan Diploma/Akper (57,7\%).

2) Faktor Yang Menghambat Program Pemeriksaan Kesehatan Berkala

Pada penelitian ini dapat ditemukan beberapa faktor yang menjadi penghambat dari program pemeriksaan kesehatan berkala. Kurangnya sosialisasi dari pihak rumah sakit kepada para karyawannya sehingga karyawan 
tidak tahu sama sekali terhadap program pemeriksaan kesehatan berkala, seperti hasil wawancara berikut ini:

"Tidak tahu" (A21)

"Belum tahu untuk kesehatan berkala" (A48)

Kurangnya sosialisai juga mengakibatkan ketidak pahaman mereka terhadap program pemeriksaan kesehatan berkala, seperti terlihat pada hasil wawancara berikut ini :

"Tahu tapi saya belum pernah baca, tapi kalau kesehatan berkala untuk karyawan tiap tahun dilakukan cek kesehatan, dan Takaful itu hanya asuransi kesehatan yang tidak di kenakan biaya" (A30)

Di samping kurangnya sosialisasi dari rumah sakit, perilaku karyawan terhadap program pemeriksaan kesehatan berkala juga menjadi salah satu faktor penghambat, seperti terlihat pada hasil wawancara berikut ini :

"Kalau tidak sakit ya tidak periksa. Jarang sekali di sini seharusnya antusias" (B44)

Perilaku karyawan merupakan faktor internal dari masing-masing individu, sehingga tingkat pemahaman dan pengetahuan serta manfaat dari program pemeriksaan kesehatan berkala sangat kurang. Di samping kedua faktor tersebut di atas faktor tidak ada sanksi bagi karyawan yang tidak mau mengikuti program tersebut sehingga karyawan kurang memperhatikan program tersebut. Karyawan yang tidak mengikuti program pemeriksaan kesehatan berkala hanya diingatkan saja untuk melakukan pemeriksaan.

"Tidak ada. Tapi misalkan belum, nanti di telpon dan di ingatkan lagi. Nanti datang ke unit sapa saja yang belum nanti di daftarkan. Biasanya yang dapat untuk karyawan masa kerja lima tahun ke atas" (E7)

"Tidak ada, tetapi selalu diingatkan" (E8)

Karyawan yang tidak mengikuti program pemeriksaan kesehatan berkala tidak diberikan sanksi serta tidak ada tindakan dari rumah sakit.

"Sanksi tidak ada, tapi kesadaran semua ikut" (F22)

"Sanksi kayaknya tidak ada. Saya belum dengar" (F23)

"Sanksi tidak ada tapi teguran saja" (F26)

Sanksi yang diberikan terhadap karyawan yang tidak mengikuti program pemeriksaan kesehatan berkala hanya teguran saja sehingga program tersebut menjadi kurang berjalan sebagaimana mestinya.

3) Ketaatan Karyawan dalam Mengikuti Pemeriksaan Kesehatan Berkala

Pemeriksaan kesehatan berkala bagi karyawan yang sudah lama bekerja pada umumnya aktif dalam pemeriksaan kesehatan.

"Selalu ikut. Setiap itu ada edaran, nanti disuruh ke lab dan di vaksin melalui undangan dan di vaksin. Biasanya yang ikut masa kerja yang dua atau tiga tahun baru dapat edaran" (C12)

"Saya selalu ikut, biasanya selalu di ikutkan karena tempat saya kebetulan yang berisiko tinggi jadi selalu di ikutkan" (C15)

KES MAS Vol. 5, No. 1, Januari $2011: 1$ - 67 
Pada dasarnya karyawan menunggu pemberitahuan dari rumah sakit untuk mengikuti pemeriksaan kesehatan.

"Tergantung dapat undangan. Seharusnya keseluruhan karyawan, tapi nyatanya seperti ini" (C29)

Pemeriksaan kesehaatan berkala bagi karyawan yang baru belum diikutkan dalam program pemeriksaan berkala.

"Belum pernah, karena baru satu tahun bekerja disini. Awal masuk itu cuma sekedar tes kesehatan saja" (C24)

4) Alasan Karyawan Melakukan Pemeriksaan Kesehatan Berkala

Pada hasil penelitian ini alasan karyawan melakukan pemeriksaan kesehatan berkala yaitu untuk perlindungan diri.

"Perlindungan diri" (D11)

"Yang pertama tentunya untuk menjaga diri, proteksi diri kita sehingga tidak tertular dan menulari" (D14)

"Untuk melindungi diri sendiri, jadi saya ikuti karena resiko pekerjaan terlalu banyak di sini. Di HD sangat ketat berhubungan dengan darah jadi resikonya terlalu tinggi" (D24)

Selain untuk melindungi diri, karyawan melakukan pemeriksaan kesehatan berkala yaitu untuk mengetahui kesehatannya.

"Untuk mengetahui kesehatan" (D17)

5) Pelayanan Kesehatan Kerja Di RSU PKU Muhammadiyah

Pelayanan kesehatan kerja bagi karyawan secara kuantitatif masih sangat minim yaitu pemeriksaan berkala sekali dalam setahun.

"Setiap satu tahun sekali untuk pemeriksan laboratorium. Kalau imunisasi bagi siapa yang mau, jadi sukarela." (H1)

Pemeriksaan kesehatan berkala 1 (satu) kali setahun tetapi dengan cara bergilir, sehingga pemeriksaan kesehatan berkala tiap karyawan bisa lebih dari 1 (satu) tahun.

"Dua tahun sekali berkalanya seperti cek up darah dan rontgen" (H25)

Pada dasarnya rumah sakit telah memberikan pelayanan kesehatan kerja secara gratis.

"Semua biaya ini gratis" (I3)

"Tidak dikenakan biaya. Kalau memerlukan tindak lanjut lagi nanti ada juga jaminan Takaful untuk tanggungan semua karyawan" (I29)

Pelayanan kesehatan kerja pada dasarnya sudah baik namun masih perlu ditingkatkan baik secara kualitas maupun kuantitasnya.

"Harapannya cek kesehatan berkala itu di lakukan setiap satu tahun sekali dan untuk semua karyawan. Karena selama ini yang di programkan dari RS hanya untuk beberapa orang saja" (J9) 
Pelayanan kesehatan kerja juga harus sesuai dengan SOP sehingga dapat memenuhi persyaratan kesehatan.

"Harapannya perlindungan kerja. Untuk HD harus ada seragam sendiri, pake masker, sarung tangan anti darah, hal-hal itu harusnya dari RS diperhatikan. Tapi ini seragamnya masih seragam biasa, kan kita langsung terkontaminasi. Tapi kita pernah mengajukan mungkin masih dalam proses" (J25)

\section{b. Pembahasan}

\section{1) Faktor yang Menghambat Program Pemeriksaan Kesehatan Berkala}

WHO $(1988)^{9}$ menyatakan bahwa di dalam program-program kesehatan, untuk mengubah perilaku masyarakat dapat dilakukan dengan tiga cara yaitu: (1) menggunakan kekuatan atau kekuasaan atau dorongan. Perubahan perilaku dapat dipaksakan kepada sasaran sehingga ia mampu melakukan seperti yang diharapkan. Cara ini dapat ditempuh dengan adanya peraturan-peraturan yang harus di patuhi; (2) memberikan informasi-informasi tentang cara kerja yang sehat, menghindari penyakit akibat kerja dan sebagainya sehingga dapat meningkatkan pengetahuan; dan (3) diskusi dan partisipasi sebagai peningkatan cara kedua agar pengetahuan sebagai dasar perilaku diperoleh secara mantap dan lebih mendalam. Pada penelitian ini dapat ditemukan tiga faktor yang menjadi penghambat dari program pemeriksaan kesehatan berkala yaitu kurangnya sosialisi, perilaku karyawan dan tidak adanya sanksi.

Bagaimanapun baiknya program namun apabila sosialisasi dalam hal ini penyampaian informasi seperti jadwal, maupun tujuan maka pemeriksaan kesehatan berkala tidak dapat berjalan dengan lancar. Pada penelitian ini dapat dilihat dari beberapa hasil wawancara bahwa ada yang menyatakan bahwa pemeriksaan kesehatan berkala dilakukan 6 (enam) bulan, 1 (satu) kali setahun, 2 (dua) atau 3 (tiga) kali setahun menunjukkan bahwa tidak persepsi ataupun jadwal yang jelas mengenai waktu diselenggarakan program pemeriksaan kesehatan berkala ini. Pihak rumah sakit biasanya memberikan undangan ataupun pemberitahuan tentang adanya pemeriksaan berkala tersebut. $\mathrm{Hal}$ ini tentu saja akan mempengaruhi tingkat kehadiran karyawan dalam program tersebut karena kemungkinan pemeriksaan kesehatan berkala bersamaan dengan shift kerja.

Perilaku K3 merupakan refleksi kejiwaan seseorang dalam bentuk aktivitas aktif maupun pasif mengenai kesehatan dan keselamatannya dalam kaitannya dengan bekerja, rekan kerja dan lingkungan kerja yang bertujuan untuk pencegahan kecelakaan kerja dan penyakit akibat kerja. ${ }^{10}$ Pada penelitian ini dapat dilihat bahwa banyak karyawan yang melakukan pemeriksaan kesehatan berkala jika sakit saja. Hal ini menunjukkan bahwa perilaku karyawan terhadap program pemeriksaan kesehatan berkala masih kurang sehingga kepedulian mereka terhadap program tersebut juga kurang. Perilaku yang kurang baik bisa disebabkan kurangnya pengetahuan tentang manfaat dari program pemeriksaan kesehatan berkala.

Pada dasarnya sanksi selain memberikan fungsi jera juga dapat bermanfaat atas lancar atau tidaknya sebuah program. Karyawan yang tidak mengikuti program pemeriksaan kesehatan berkala tidak diberikan sanksi apapun baik berupa peringatan atau penundaan gaji atau kepangkatan. Hal ini akan mengakibatkan karyawan kurang memperhatikan dari program tersebut. Karyawan yang tidak mendukung program tersebut tidak mempunyai halangan apapun untuk tidak mengikuti program pemeriksaan kesehatan berkala. Lain 
halnya jika program pemeriksaan kesehatan berkala ada sanksinya, maka semua karyawan akan mengikuti program tersebut.

2) Ketaatan Karyawan dalam Mengikuti Pemeriksaan Kesehatan Berkala

Ketaatan adalah salah satu sikap dan perilaku yang berniat untuk mematuhi segala peraturan organisasi. Upaya dalam mentaati peraturan tidak didasarkan perasaan takut atau terpaksa. ${ }^{11}$ Perilaku manusia adalah suatu keadaan yang seimbang antara kekuatan-kekuatan pendorong dengan kekuatan-kekuatan penahan. Perilaku bisa berubah jika terjadi ketidak seimbangan antara dua faktor tersebut. ${ }^{12}$ Hasil penelitian ini menunjukkan bahwa tingkat ketaatan karyawan dalam mengikuti pemeriksaan kesehatan dapat dikatakan cukup baik yaitu sebanyak 65\%. Umumnya karyawan menunggu pemberitahuan maupun undangan dari rumah sakit untuk mengikuti pemeriksaan kesehatan berkala tersebut. Karyawan yang mendapatkan undangan atau pemberitahuan banyak yang mengikuti program tersebut, tetapi apabila tidak ada pemberitahuan atau undangan mereka tidak akan melakukan pemeriksaan kesehatan berkala. Tidak banyak karyawan yang aktif mencari tahu jadwal dari pelaksanaan program tersebut. Karyawan yang belum lama bekerja di rumah sakit tentunya tidak begitu hafal dengan jadwal dari pemeriksaan kesehatan berkala tersebut.

Rumah Sakit Umum PKU Muhammadiyah Yogyakarta mempunyai prosedur tetap dalam pemeriksaan kesehatan berkala untuk karyawan yaitu karyawan resiko tinggi dan karyawan resiko rendah. Karyawan resiko tinggi adalah karyawan-karyawan yang berada di unit-unit yang langsung berhubungan dengan perawatan pasien yaitu: Radiologi, laboratorium, Linen, sanitasi, ICU/ICCU, IGD, IBS, kamar bersalin, Pav Shafa, Arafah, Kamar Bayi, Pav Muzhalifah, Zamzam, Raudhah, Mina, Multazam, Ibnu Shina, Marwah, Kelompok Dokter Umum, Poliklinik dan rehabilitasi Medik. Karyawan-karyawan dengan resiko tinggi ini RSU PKU Muhammadiyah Yogyakarta melakukan pemeriksaan yang dilakukan tiap 2 (dua) tahun sekali ${ }^{7}$ yaitu:

a) Pemeriksaan fisik

b) Pemeriksaan Laboratorium : darah rutin, Urin rutin, SGOT, SGPT, Ureum, Creatinin, HbsAg, Anti HBS, Sputum BTA

c) Pemeriksaan radiologi: Ro thorax

Karyawan risiko rendah adalah karyawan-karyawan yang berada di unitunit selain pada unit untuk karyawan risiko tinggi yaitu Pemeliharaan Medik, CSSD, Gizi, Bagian Umum dan Keuangan. Karyawan-karyawan dengan resiko rendah ini RSU PKU Muhammadiyah Yogyakarta melakukan pemeriksaan yang dilakukan tiap 3 (tiga) tahun sekali ${ }^{7}$ yaitu:

a) Pemeriksaan fisik

b) Pemeriksaan Laboratorium : darah rutin, Urin rutin

c) Pemeriksaan radiologi: Ro thorax

\section{3) Alasan Karyawan Melakukan Pemeriksaan Kesehatan Berkala}

Pada penelitian ini ditemukan dua alasan pokok yang mendasari karyawan melakukan pemeriksaan kesehatan berkala yaitu untuk melindungi/ menjaga diri dan mengetahui kesehatan. Penyakit Akibat Kerja (PAK) adalah penyakit yang mempunyai penyebab yang spesifik atau asosiasi yang kuat dengan pekerjaan, yang pada umumnya terdiri dari satu agent penyebab yang sudah diakui. Selanjutnya, penyakit yang berhubungan dengan pekerjaan (work related disease) adalah penyakit yang mempunyai beberapa agent penyebab, dimana faktor pada pekerjaan memegang peranan bersama dengan faktor 
risiko lainnya dalam berkembangnya penyakit yang mempunyai agent penyebab yang komplek. ${ }^{8}$ Pemeriksaan kesehatan berkala ini sangat penting bagi petugas medis maupun non medis yang selalu bersentuhan dengan penyakit dengan risiko berat seperti HIV, HBsAg, Hepatitis dan sebagainya. Karyawan ini sangat berkepentingan untuk melindungi atau menjaga diri dari tertularnya penyakitpenyakit tersebut. Selain untuk melindungi diri, karyawan-karyawan tersebut juga berkepentingan dengan kondisi kesehatan mereka. Pekerjaan yang berhubungan dengan pasien tentu saja rentan dengan penyakit, infeksi dan lain sebagainya. Hal ini mengharuskan mereka mengetahui kondisi kesehatan untuk melakukan tindakan preventif.

\section{4) Pelayanan Kesehatan Kerja di RSU PKU Muhammadiyah}

Rumah Sakit adalah suatu tempat atau sarana dimana orang mendapatkan pelayanan kesehatan sekaligus tempat orang bekerja dimana dibutuhkan sumber daya manusia yang berkualitas dan produktif guna mencapai pelayanan kesehatan yang berkualitas. Organisasi K3RS PKU Muhammadiyah Yogyakarta dalam pengorganisasiannya melibatkan seluruh unsur terkait sesuai dengan tanggung jawab masing-masing. Namun untuk menjamin terlaksananya K3 dengan baik diperlukan keterpaduan antar fungsi dalam organisasi dan antar jenjang dalam fungsi serta harus dinyatakan secara jelas dalam uraian.

Pelayanan kesehatan kerja di RSU PKU Muhammadiayah masih kurang dimana secara kuantitatif pemeriksaan kesehatan berkala frekuensinya sangat minim yaitu 2 (dua) tahun sekali bagi karyawan yang tingkat risikonya tinggi dan 3 (tiga) tahun sekali bagi karyawan yang tingkat resikonya rendah dan tidak dilakukan pada setiap karyawan akan tetapi secara bergiliran. Selain itu standar pelayanan kesehatan kerja yang selama ini diterapkan juga masih perlu ditingkatkan.

Masih terbatasnya ruangan seperti kemoterapi yang belum mempunyai ruangan khusus, masih bercampur radiasi kemoterapi yang sangat rentan jika terkena manusia. Akibatnya bisa mengakibatkan bahaya yang lain. Demikian juga peralatan-peralatan harus dilengkapi seperti pada bagian HD harus ada seragam sendiri, masker, sarung tangan anti darah dan lainnya.

Situasi K3 RSU PKU Muhammadiyah Yogyakarta sudah banyak yang dilaksanakan namun ada juga yang belum dilaksanakan. Pelaksanaan kesehatan kerja yang sudah dilaksanakan (Rumah Sakit Umum PKU Muhammadiyah Yogyakarta, 2002) adalah: (a) pemeriksaan kesehatan pra pekerjaan untuk karyawan baru; (b) pemberian santunan kesehatan, untuk seluruh karyawan dan untuk penyakit umum; (c) pemeriksaan kesehatan khusus, untuk kecelakaan kerja; (d) poliklinik karyawan dan dokter perusahaan; (e) penyelenggaraan makanan di tempat kerja; (f) pemberian paket tambahan gizi untuk karyawan radiologi; (g) pemberian tablet Fe-folat, untuk karyawan wanita; (h) penempatan karyawan sesuai dengan kapasitas karyawan; (i) membantu usaha rehabilitasi akibat kecelakaan kerja; (j) pelatihan tentang $\mathrm{K} 3$, untuk seluruh karyawan; (k) orientasi K3, untuk karyawan baru; (I) olah raga untuk karyawan, sesuai minat masing-masing karyawan; $(\mathrm{m})$ pemantauan pelaksanaan K3; (n) alat pelindung diri, setiap unit kerja sesuai kebutuhan; (o) pemantauan lingkungan kerja; $(p)$ imunisasi Hepatitis B untuk karyawan Unit Risiko Tinggi. Pelaksanaan kesehatan kerja yang belum dilaksanakan adalah: (a) pemeriksaan kesehatan berkala untuk seluruh karyawan sesuai dengan risiko unit kerja; (b) setiap karyawan mampu melakukan P3K/BLS, pelatihan baru hanya diberikan untuk beberapa karyawan saja; (c) ketaatan terhadap larangan merokok. 
Hasil penelitian ini dapat dijadikan sebagai masukan bagi Pimpinan RS bersama-sama dengan Tim PK3 RS untuk melakukan perbaikan-perbaikan sebagai tinjauan ulang untuk mengatasi kekurangan-kekurangan yang ada, serta menentukan tujuan dan sasaran yang baru.

\section{SIMPULAN DAN SARAN}

\section{a. Simpulan}

Berdasarkan hasil penelitian yang dilakukan pada karyawan RSU PKU Muhammadiyah Yogyakarta tahun 2010 dapat disimpulkan sebagai berikut ini:

1) Faktor-faktor yang dapat menghambat terlaksananya pemeriksaan kesehatan pada karyawan di RSU PKU Muhammadiyah adalah:

a) Kurangnya sosialisai terhadap program pemeriksaan kesehatan pada karyawan.

b) Perilaku karyawan terhadap program pemeriksaan kesehatan.

c) Tidak adanya sanksi dari rumah sakit.

2) Tingkat ketaatan karyawan dalam mengikuti pemeriksaan kesehatan berkala di RS PKU Muhammadiyah Kota Yogyakarta cukup baik sebanyak 65\%.

3) Alasan karyawan dalam melakukan pemeriksaan kesehatan berkala di RS PKU Muhammadiyah Kota Yogyakarta yaitu:

a) Melindungi atau menjaga diri.

b) Mengetahui kesehatan.

4) Tingkat pelayanan kesehatan kerja di RSU PKU Muhammadiyah Kota Yogyakarta cukup baik namun masih ada yang belum dilaksanakan seperti pemeriksaan kesehatan berkala untuk seluruh karyawan sesuai dengan risiko unit kerja, setiap karyawan mampu melakukan P3K/BLS dan ketaatan terhadap larangan merokok

\section{b. Saran}

1) Bagi Pimpinan RS PKU Muhammadiyah Yogyakarta, hendaknya memperbaiki perilaku karyawan dengan training motivasi dan memberlakukan sanksi bagi karyawan yang tidak taat terhadap K3.

2) Bagi Pimpinan PK3 RS PKU Muhammadiyah Yogyakarta, hendaknya dapat meminimalisir faktor penghambat pemeriksaan kesehatan pada karyawan dengan sosialisasi yang lebih inten yaitu dengan memberikan penyuluhan K3 mengenai kesehatan kerja dan memberikan training motivasi kepada karyawan rumah sakit.

3) Bagi Karyawan RS PKU Muhammadiyah Yogyakarta, hendaknya mematuhi semua peraturan maupun prosedur dari K3 terutama dengan meningkatkan kesadaran untuk melakukan pemeriksaan kesehatan, meningkatkan P3K/BLS serta mentaati larangan merokok.

\section{DAFTAR PUSTAKA}

1. Christiono, Analisa Sistem Manajemen Keselamatan dan Kesehatan Kerja Sebelum dan Sesudah Akreditasi di RS Pantiwilasa Citarum, Tesis, Program Pasca Sarjana Universitas Diponegoro, Semarang, 2004

2. Departemen Kesehatan RI., Pedoman Manajemen Kesehatan Kerja (K3) di Rumah Sakit, http://depkes.go.id, diakses 06 Agustus 2009, Yogyakarta, 2007

3. Sukar, Agustina Lubis, Athena, et al., Noise Impact Of 6000 and $8000 \mathrm{~Hz}$ Frequency For Safety Employee, Jurnal Ekologi Kesehatan, Vol 2 Nomor 1: 185-191, 2003 
4. Direktorat Pengawasan Norma Keselamatan dan Kesehatan Kerja, Direktorat Jenderal Pembinaan Pengawasan Ketenagakerjaan (DPNK3), Program Perlindungan dan Pengembangan Lembaga Tenaga Kerja dan Transmigrasi RI., Himpunan Peraturan Perundang-undangan Keselamatan dan Kesehatan Kerja, Direktorat Pengawasan Norma Keselamatan dan Kesehatan Kerja, Direktorat Jenderal Pembinaan Pengawasan Ketenagakerjaan (DPNK3), Jakarta, 2006

5. Aditama, T.Y, dan Hastuti T., Kesehatan dan Keselamatan Kerja, Universitas Indonesia (UI) Press, Jakarta, 2006

6. Keselamatan dan Kesehatan Kerja, http://www.aimititi.netfirms.com, diakses pada tanggal 01 Agustus 2008, Yogyakarta, 2003

7. Rumah Sakit PKU Muhammadiyah Yogyakarta, Buku Pedoman Keselamatan Kerja, Kebakaran dan Kewaspadaan Bencana, Yogyakarta, 2002

8. Sugiono, Metodologi Penelitian Kuantitatif Kualitatif dan R\&D, Alfabeta, Bandung, 2007

9. World Health Organization (WHO), Pendidikan Kesehatan, Pedoman Pelayanan Kesehatan Dasar, Alih bahasa oleh Tjitarsa IB, 1992, Penerbit ITB, Bandung, 1988

10. Setyaningrum, R., Ketaatan Penggunaan Alat Pelindung Pendengaran dan Stres Kerja Pada Karyawan di Area Bising PT. Mega Andalan Kalasan (MAK) Yogyakarta, Tesis, Program Pascasarjana, Universitas Gadjah Mada, Yogyakarta, 2009

11. Helmi, Alvin Fadilla, Disiplin Kerja. Buletin Psikologi, Tahun IV, Nomor 2, Desember 1996, Fakultas Psikologi Universitas Gajah Mada, Yogyakarta, 1996

12. Notoatmodjo, Pengantar Pendidikan Kesehatan dan IImu Perilaku Kesehatan, Andi Offset, Yogyakarta, 1997

13. ILO, Accident Prevention (A Workers Education Manual), International Labour Office, Geneve, 1986 